Research Article

\title{
Crude ethanolic leaf extracts of Citropsis articulata: a potential phytomedicine for treatment of male erectile dysfunction associated with testosterone deficiency
}

\author{
Patrick Vudriko, Martin K. Baru, John Kateregga, James G. Ndukui*
}

\begin{abstract}
Department of Veterinary
Pharmacy, Clinics and Comparative Medicine, School of Veterinary Medicine and Animal Resources, College of Veterinary Medicine, Animal Resources and Biosecurity, Makerere University, Kampala, Uganda
\end{abstract}

Received: 29 November 2013 Accepted: 15 December 2013

\section{*Correspondence to: \\ James G. Ndukui, \\ Email:ndukuiga@gmail.com}

(C) 2014 Vudriko P et al. This is an open-access article distributed under the terms of the Creative Commons Attribution Non-Commercial License, which permits unrestricted non-commercial use, distribution, and reproduction in any medium, provided the original work is properly cited.

\begin{abstract}
Background: Erectile dysfunction is the inability to sustain erection of the penis firm enough for sexual intercourse in males. Citropsis articulata is used locally by communities in Uganda for the management of erectile dysfunction. The current study evaluated the effect of ethanolic leaf extract of $C$. articulata on the serum level of testosterone and mounting frequency in Male albino rats.

Methods: The study animals were divided into four groups and the extract groups dosed daily orally with $400 \mathrm{mg} / \mathrm{kg}$ and $600 \mathrm{mg} / \mathrm{kg}$ of extract for three weeks. Sildenafil citrate $(1 \mathrm{mg} / \mathrm{kg})$ and distilled water $(10 \mathrm{ml} / \mathrm{kg})$ were used as positive and negative control respectively. The mounting frequencies of the males exposed to estrus induced females rats on day (7 and 21), testosterone levels (day 21) and phytochemicals present in the extract were determined.

Results: At $400 \mathrm{mg} / \mathrm{kg}$ and $600 \mathrm{mg} / \mathrm{kg}$, both testosterone level and mounting frequency increased significantly $(\mathrm{p}<0.05)$ by third week. The mean testosterone level at $600 \mathrm{mg} / \mathrm{kg}(2.678 \mathrm{ng} / \mathrm{ml})$ of the extract was higher than that of group treated with $1 \mathrm{mg} / \mathrm{kg}$ sildenafil citrate $(2.18 \mathrm{ng} / \mathrm{ml})$. The aphrodisiac activity of this extract may be associated with presence of saponins and basic alkaloids in the plant extract.

Conclusions: Taken together, the crude leaf extracts of $C$. articulata could be used as a cheap alternative for the treatment of low libido due to testosterone deficiency. However, further studies are needed on the safety profile and the identification of the molecules responsible for the biological activity of the plant extract.
\end{abstract}

Keywords: Citropsis articulata, Aphrodisiac, Testosterone

\section{INTRODUCTION}

Citropsis articulata, also locally known as the Omuboro is a popular plant in Central and Western Uganda for its claimed aphrodisiac properties. The plant naturally grows in forests and locals uproot it to obtain the roots for treatment of erectile dysfunctions. The root of this plant has been cherished as one of the most valuable herbal Viagra by most rural communities in Uganda. ${ }^{1}$ The fast disappearance of these culturally important medicinal plants due to poor utilization practices certainly pose major threat towards a looming extinction. Conservationists in the country are concerned that demand for the roots of the plant threatens the survival of this species' genetic diversity in conservation areas like Mabira forest. ${ }^{2}$ The roots are either chewed while fresh/dried or pounded into powder form and then mixed with water to form a concoction. Other plants like Warburgia ugandenesis, Cola acuminata, Prunus americana and Ekebergia capensis have been used in the 
management of erectile dysfunction. ${ }^{2,3}$ The use of medicinal plants for boosting male sexual performance is also popular in China. ${ }^{4}$ The increase in testosterone level has been reported as one of the mechanisms through which medicinal plants boosts sexual performance in male. $^{5}$ Testosterone is a steroid hormone that is responsible for the development and maintenance of the masculine characteristics. Low testosterone levels cause countless problems for both sexes. ${ }^{6}$ According to Caruthers et $a l,{ }^{7} 20-50 \%$ of healthy men between the ages of 50 and 70 have sub-normal levels of testosterone and up to $5 \%$ of all men are at risk of low testosterone states. Low levels of testosterone may be caused by aging (andropause) cells of the testes, diseases affecting the hypothalamus and pituitary glands, drugs and genetic diseases. ${ }^{8}$ The current study was designed to verify the traditional claims on the aphrodisiac properties of the leaves of C. articulata.

\section{METHODS}

\section{Study design}

This was an experimental study in which the effects of ethanolic leaves extract of $C$. articulata on mounting frequency and serum testosterone levels was determined and compared to reference drugs (Sildenafil citrate) used for the treatment of erectile dysfunction. The method by Trease et al. ${ }^{9}$ was used to determine the phytochemical composition of the extract.

\section{Collection of the plant materials and identification}

The leaves of $C$. articulata were obtained from Mabira forest which is 25 kilometers from Kampala to the east of Uganda. They were cut using a knife and packed into a nylon sack and transported to the Pharmacology and Toxicology Research Laboratory, (COVAB). Authentification of the plant was done by a Botanist in the Herbarium, College of Natural Sciences - Makerere University and voucher specimen No: 41658 was deposited.

\section{Drying of plant materials}

The leaves of $C$. articulata were first washed using clean tap water to remove visible dirt and dried under the shade in the Pharmacology and Toxicology Research Laboratory unit to a constant weight.

\section{Extraction process}

The air dried plant leaves were pounded using a mortar and pestle to increase the surface area for extraction of the active ingredients and solvent interaction. The pounded leaves of $C$. articulata were weighed and $500 \mathrm{~g}$ was soaked in $2000 \mathrm{ml}$ of $70 \%$ ethanol in a 2.5 liters Amber bottles. The mixture was left for three days with intermittent shaking, twice daily to optimize extraction of the chemical constituents from the leaves. The extract was allowed to decant, filtered using cotton wool and further finely filtered using Whatman no: 1 filter paper. The filtrate was concentrated with a rotary evaporator at a temperature of $50^{\circ} \mathrm{C}$. The resultant residue concentrate (Crude extract) was dried in hot air oven at temperature of $40^{\circ} \mathrm{C}$ until a semi-dry residue was obtained. The dry extract was weighed and stored in a refrigerator at a temperature of $4{ }^{\circ} \mathrm{C}$ prior to administration to the experimental animals and phytochemical analysis.

\begin{abstract}
Animal selection
Healthy, adult male albino rats weighing 170-180g, aged 8 weeks were used in this study. The rats were given standard commercial rodent diet (Uga-Chick Ltd), water ad libitum and kept in a room at temperature of $25 \pm 1^{\circ} \mathrm{C}$, relative humidity $65 \pm 2 \%$ and $12 \mathrm{hrs}$ light /dark in the Pharmacology and Toxicology Research Laboratory.
\end{abstract}

\section{Grouping of experimental animals}

The rats were randomly divided into four different groups $(\mathrm{n}=6)$ and kept in cages labeled as group I, II, III and IV. Each albino rat in the different groups was labeled on the tail using marker pen and their weight determined using weighing balance (OHAUS NVT 1601/1). Groups I and II contained male albino rats treated with 400 and 600 $\mathrm{mg} / \mathrm{kg}$ of extract orally respectively. Whereas groups III and IV contained rats that were treated with $1 \mathrm{mg} / \mathrm{kg}$ sildenafil citrate (Kamagra, B.No:0561H, India) and $10 \mathrm{ml} / \mathrm{kg}$ distilled water as positive and negative controls respectively. Rats in each experimental group were treated once every day for twenty one days.

\section{Estrus induction in females}

Twelve female rats were treated with first dose of estradiol benzoate $(0.5 \mathrm{mg} / \mathrm{kg})$ and progesterone (10 $\mu \mathrm{g} / 100 \mathrm{~g}$ ) intraperitoneally to induce estrus. On day 3 post estrus inductions, a second dose of the above hormones were administered four hrs prior to the exposure of the estrus female to the treated males in various groups. At the time of observation, males from each group were kept in individual cages and exposed to an estrus female rat. The combined animals were allowed to acclimatize for 25 mins before determination of the mounting frequency (attempt to mount). The observations were done on days 7 and 21 of the experiment.

\section{Testosterone assay}

Blood was collected on day twenty second of the experiment after last administration of the plant extract to determine the level of serum testosterone. The rats were anesthetized using diethyl ether in a rectangular glass and a cardiac puncture was performed. Two milliliters of blood was collected in clean sterile non-EDTA coated vacutainers for testosterone assay. The whole blood composition was separated by centrifugation at 33.5 revolutions per second for 15 minutes using a Uniscope laboratory centrifuge (Model SM800B, Surgifriend Medicals, Essex, UK). The serum was collected using a 
Pasteur pipettes into a clean, dry, vials which was loaded in the Cobas E911 Immunolyser machine for the analysis of testosterone levels by the use of indirect immune assay techniques.

\section{Phytochemical analysis}

Methods by Trease et $a l^{9}{ }^{9}$ were used to qualitatively determine the phytochemical constituents in the ethanolic crude leaves extract of $C$. articulata.

\section{Data analysis}

The data of serum testosterone level and mounting frequencies was expressed as Mean \pm SEM. Graph pad prism vs 5.1 (USA. Inc ) was used for ANOVA and post hoc multiple comparison test (Dunnet test) was used, with $\mathrm{p}<0.05$ considered statistically significant.

\section{RESULTS}

Qualitative phytochemical analysis revealed strong presence of catechol tannins, moderate presence of saponins, alkaloid salts, reducing compounds and coumarins; quaternary bases and oxides amines, streroid gylcosides and cardiac glycosides aglycones were weakly present (Table 1).

Table 1: Phytochemical profiles of the ethanolic leave extracts of $C$. articulate.

\begin{tabular}{|ll|}
\hline Phytochemicals analysed & Inference \\
\hline Saponin & ++ \\
\hline Catechol tannins & +++ \\
\hline Reducing compounds & ++ \\
\hline Alkaloid salts & ++ \\
\hline Quaternary bases and oxides amines & + \\
\hline Coumarins & ++ \\
\hline Steroid glycosides & + \\
\hline Cardiac glycosides aglycones & + \\
\hline Key: +++ = strongly present, $++=$ moderately present, + \\
$=$ weakly present, $-=$ absent & \\
\hline
\end{tabular}

\section{Effect of extract on mounting frequency}

There was a significant increase $(\mathrm{p}<0.05)$ in the mounting frequency of the male rats treated with $600 \mathrm{mg} / \mathrm{kg}$ on day 21 which was comparable to that of rats treated with 1 $\mathrm{mg} / \mathrm{kg}$ sildenafil citrate (Table 2).

Table 2: Table 2: Effect of $C$. articulata on mounting frequency in male albino rats.

\begin{tabular}{|llllll|}
\hline & & Mouning Frequency at day 7 & Mounting Frequency at day 21 \\
\hline Grouping & Treatment & Mean \pm SEM & $95 \% \mathrm{CI}$ & Mean \pm SEM & $95 \%$ CI \\
\hline Group I & $400 \mathrm{mg} / \mathrm{kg} \mathrm{E}$ & $2.75 \pm 0.48$ & $2-4$ & $3.75 \pm 0.25^{\mathrm{d}}$ & $3-4$ \\
\hline Group II & $600 \mathrm{mg} / \mathrm{kg} \mathrm{E}$ & $3.5 \pm 0.47$ & $2-5$ & $5.0 \pm 0.41^{\mathrm{e}}$ & $4-6$ \\
\hline Group III & $1 \mathrm{mg} / \mathrm{kg} \mathrm{SC}$ & $4.25 \pm 0.48^{\mathrm{c}}$ & $3-5$ & $6.250 \pm 0.48^{\mathrm{f}}$ & $5-7$ \\
\hline Group IV & $10 \mathrm{ml} / \mathrm{kg} \mathrm{DW}$ & $2.0 \pm 0.41$ & $1-3$ & $2.25 \pm 0.48$ & $1-3$ \\
\hline
\end{tabular}

Value presented as Mean \pm SEM ( $n=4)$; E- extract; SC- Sildenafil citrate; DW- distilled water; Comparison with negative control: $p$ value $(\mathrm{c}=0.0117 ; \mathrm{d}=0.0321 ; \mathrm{e}=0.0047$ and $\mathrm{f}=0.001) ; \mathrm{n}=4$

\section{Effect of extract of C. articulata on serum testosterone} level

There was dose dependent increase in serum testosterone among male rats in the groups treated with the extract. At a dose rate of $400 \mathrm{mg} / \mathrm{kg}$ and $600 \mathrm{mg} / \mathrm{kg}$, the serum testosterone levels were $1.2975 \mathrm{ng} / \mathrm{ml}$ and $2.6775 \mathrm{ng} / \mathrm{ml}$ respectively. The above testosterone levels were statistically significant $(\mathrm{p}<0.05)$ when compared to the negative control. At $600 \mathrm{mg} / \mathrm{kg}$ the testosterone level $(2.6775 \mathrm{ng} / \mathrm{ml})$ was greater than that of $1 \mathrm{mg} / \mathrm{kg}$ Sildenafil citrate $(2.18 \mathrm{ng} / \mathrm{ml})$ (Table 3$)$.

Table 3: Effect of $C$. articulata on testosterone level.

\begin{tabular}{|l|lll|}
\hline Group & Treatment & Mean \pm SEM $(\mathrm{ng} / \mathrm{ml})$ & $\mathbf{9 5 \%}$ CI \\
\hline Group I & $400 \mathrm{mg} / \mathrm{kg}$ Extract & $1.345 \pm 0.08986^{\mathrm{i}}$ & $1.13-1.57$ \\
\hline Group II & $600 \mathrm{mg} / \mathrm{kg}$ Extract & $2.678 \pm 0.1160^{\mathrm{j}}$ & $2.34-2.87$ \\
\hline Group III & $1 \mathrm{mg} / \mathrm{kg}$ Sildanfil citrate & $2.180 \pm 0.09354^{\mathrm{k}}$ & $2.02-2.45$ \\
\hline Group IV & $1 \mathrm{ml}$ Dist.water & $0.7500 \pm 0.2345$ & $0.25-1.15$ \\
\hline
\end{tabular}

Value expressed as Mean \pm SEM $(n=6)$; Comparison with negative control: $p$ values $(I=0.0762 ; j=0.001 ; k=0.001)$ 


\section{DISCUSSION}

The increased mounting frequency on day 21 could be attributed to the increased level of free serum testosterone level in the blood. The increase in mounting frequency due to testosterone was also reported by Kesler et al. ${ }^{10}$ Indeed, the rats that received the extract at the dose rate of $600 \mathrm{mg} / \mathrm{kg}$ had three fold increase in the level of testosterone compared to the group that was given only distilled water. This result indicates that the extract had the ability to influence synthesis and release of testosterone from the testis into blood circulation. Such effect could be attributed to the presence of phytochemicals such as saponins, and coumarins that have been previously reported ${ }^{11}$ to increase testosterone level. Similar studies ${ }^{4}$ reported that the increase in testosterone level following treatment with Fenugreek seeds was attributed to the saponins which have the ability to cause release of Luteinizing hormone ( $\mathrm{LH})$ that leads to the boost in testosterone levels. It also stimulates the leydig cells of the testes to directly increase testosterone production. ${ }^{11}$ In the current study we found moderate presence of alkaloids in the extract. Previous study $^{12}$ has shown that alkaloids increase blood flow in the sexual organs due to vasodilatation thus sustaining male erection leading to enhanced sexual performance. Similar mechanism is responsible for the enhanced sexual performance associated with Sildenafil citrate. However, there was more pronounced sexual activity in the male rats treated with $600 \mathrm{mg} / \mathrm{kg}$ of the test extract compared to $1 \mathrm{mg} / \mathrm{kg}$ of Sildenafil citrate. Although the local communities prefer using the root back which has predisposed the plant to extinction, our study provides a scientific evidence for the adoption of the leaves as an alternative plant part for traditional management of erectile dysfunction. This approach presents a timely opportunity for sustainable utilization of the plant biodiversity and its conservation for the future generation.

\section{CONCLUSION}

The increase in sexual performance and serum testosterone level in the extract treated rats validates the traditional use of $C$. articulata in the management of erectile dysfunction in Central and Western parts of Uganda. However, further investigation is needed on bioassay guided structural elucidation of the phytoactive agents and the safety profile of $C$. articulata.

\section{ACKNOWLEDGEMENTS}

The authors would like to thank the staff of the Pharmacology and Toxicology Research Lab of the College of Veterinary Medicine, Animal Resources and Biosecurity -Makerere University for their input during the entire duration of the experiment.

Funding: No funding sources

Conflict of interest: None declared
Ethical approval: Ethical clearance was obtained from the College of Veterinary Medicine, Animal Resources and Biosecurity, Makerere University; guidelines for appropriate experimental animal care and handling were also followed.

\section{REFERENCES}

1. Kamatenesi-Mugisha M. Medicinal plants used in Reproductive Health Care in Western Uganda: Documentation, Phytochemical and Bioactivity Evaluation. Makerere University; Ph.D. Thesis in Botany. 2004.

2. Kamatenesi-Mugisha $\mathbf{M}$, Oryem-Origa $\mathrm{H}$. Traditional Herbal Remedies used in the management of sexual impotence and erectile dysfunction in western Uganda, African Health Sciences. 2005;5(1):40-9.

3. Ndukui JG, Muwonge $\mathrm{H}$ and Sembajwe LF. Aphrodisiac potential and phytochemical profile of Ekebergia capensis (Cape ash) in male albino rats. Spatula DD. 2012;2(4):237-43.

4. Alevtina G, Zerihun S. Ethiopian Traditional and Herbal Medications and their Interactions with Conventional Drugs. 2009. Available at: http://ethnomed.org/clinical/pharmacy/ethiopianherb-drug-interactions. (accessed 28/10/2013).

5. National Institute of Health. Acupuncture. NHI Consensus Statement. 1997;15(5):1-34.

6. Mason R. Testosterone is your friend: A Book for Men and Women. USA: Square One Publishing; 2004: 59-70.

7. Caruthers M. The Testosterone Revolution. London: Thorsons; 2001; 124 (1): 17-28.

8. Mintz AP, Dotson A, Mukai J. Hormone modulation, low glycemic nutrition, and exercise instruction: Effects on disease risk and quality of life. Journal of Anti-Aging Medicine. 2001;4:357-71.

9. Trease GE, Evans WC. Phenols and Phenolic glycosides. Textbook of Pharmacognosy. London: Balliese, Tindall and Co Publishers; 1989; 12: 343383.

10. Kesler DJ, Troxel TR, Vincent DL, Scheffrahn NS, Noble RC. Detection of estrus with cows administered testosterone via injections and/or silastic implants. Theriogenology. 1981;15(3):32734.

11. Ang HH, Lee KL, Kiyoshi M. "Sexual arousal in sexually sluggish old male rats after oral administration of Eurycoma longifolia (Jack). J Basic Clin Physiol Pharmacol. 2004;15(3-4):303-9.

12. Dimitris C, Gournelif G, Laskarisb G, Verpoorte R. Cyclopeptide alkaloids. Nat Prod Rep 1997;14(1):75-82.

doi:10.5455/2319-2003.ijbcp20140214

Cite this article as: Vudriko P, Baru MK, Kateregga J, Ndukui JG. Crude ethanolic leaf extracts of Citropsis articulata: a potential phytomedicine for treatment of male erectile dysfunction associated with testosterone deficiency. Int J Basic Clin Pharmacol 2014;3:120-3. 